\title{
ANALISIS PENGARUH FAKTOR INTERNAL DAN EKSTERNAL TERHADAP PENGAMILAN SAHAM PERBANKAN BUMN YANG TERDAFTAR DI BEI PERIODE 2010-2014
}

\author{
Sanuri \\ sanuriaw@gmail.com \\ Universitas Ahmad Dahlan \\ Desta Rizky Kusuma \\ kusuma.desta@gmail.com \\ Universitas Ahmad Dahlan
}

\begin{abstract}
ABSTRAK
This study aims to determine the influence of factors internal and external to the return of registered banking shares Indonesia Stock Exchange in 2010-2014. The population in this study were 4 BUMN bank companies registered in Indonesia Stock Exchange period 20102014 sampling techniques used is purposive sampling. obtained by 4 state-owned bank companies included in the independent variable criterion studied is Return On Assets (ROA), Capital Adequacy Ratio (CAR), Inflation Rate, and Rate of Interest Interest and the dependent variable studied is stock returns. Analysis Techniques used is Panel Data Regression and Hypothesis test using t-test. The results showed that both variables were simultaneously independent Return On Asset (ROA) has no effect on stock returns Partially the variables of the four independent variables are Return On Assets (ROA), Capital Adequacy Ratio (CAR), Inflation and Interest Rates are only Inflation and Interest rates that have a significant effect on stock returns. R-square value $33.42 \%$.
\end{abstract}

Keywords: Return On Assets (ROA); Capital Adequacy Ratio (CAR); Inflation Rates; Interest Rates.

\section{PENDAHULUAN}

Semakin baik tingkat perekonomian suatu negara, maka semakin baik pula tingkat kemakmuran penduduknya. Tingkat kemakmuran yang lebih tinggi ini umumnya ditandai dengan adanya kenaikan tingkat pendapatan masyarakatnya. Dengan adanya peningkatan pendapatan tersebut, maka akan semakin banyak orang yang memiliki kelebihan dana, kelebihan dana tersebut dapat dimanfaatkan untuk disimpan dalam bentuk tabungan atau diinvestasikan dalam bentuk surat-surat berharga yang diperdagangkan dalam pasar modal (Laporan Tahunan BI, 2001). Bank merupakan lembaga perantara keuangan (financial intermediaries) atau sebagai perantara pemilik dana dengan pengguna dana sebagai prasaran pendukung untuk menunjang kelancaran perekonomian Disamping itu, peranan perbankan juga sangat penting karena merupakan lembaga pembiayaan yang membiayai berbagai kegiatan usaha yang produktif yang ada giliranya akan mendorong pertumbuhan ekonomi.

Menurut Ali (2006), bank didefinisikan sebagai lembaga keuangan yang memiliki izin usaha untuk beroperasi sebagai bank, yaitu menerima penempatan dana-dana yang dipercayakan masyarakat kepada bank tersebut, memberikan pinjaman kepada masyarakat dan dunia usaha pada umumnya, memberi akseptasi atas berbagai bentuk surat utang yang 
disampaikan pada bank tersebut serta menerbitkan cek. Industri Perbankan memegang peranan penting bagi pembangunan ekonomi sebagai Financial Intermediary atau perantara pihak yang kelebihan dana dengan pihak yang membutuhkan dana. Krisis moneter mengakibatkan banyaknya bank yang mengalami kredit macet. Hal tersebut mempengaruhi iklim investasi pasar modal dibidang perbankan baik secara langsung maupun tidak langsung. Dengan berinvestasi pada pasar modal dapat meningkatkan laba pada perusahaan adalah salah satu faktor yang memotivasi investor untuk berinvestasi dan juga merupakan imbalan atas keberanian investor menanggung resiko atas investasi yang dilakukannya. kedua adalah menyangkut faktor eksternal, misalnya pengaruh kebijakan moneter dan fiskal, perkembangan, Penerbitan saham bagi perbankan merupakan salah satu cara guna memenuhi tambahan dana yang dibutuhkan perusahaan. Saham merupakan salah satu instrument pasar keuangan yang paling populer dan banyak dipilih para investor di pasar modal ataupun bagi perusahaan untuk mendapatkan dana bagi kepentingan bisnis perusahaan. Dengan berinvestasi pada pasar modal dapat meningkatkan laba pada perusahaan perbankan. Investasi sendiri merupakan suatu kegiatan menempatkan dana pada satu atau lebih asset selama periode tertentu dengan harapan dapat memperoleh pendapatan atau peningkatan atas nilai investasi awal (modal) yang bertujuan untuk memaksimalkan hasil (return) yang diharapkan dalam batas risiko yang dapat diterima untuk tiap investor. Dalam hal ini dijelaskan, ada dua faktor yang mempengaruhi hubungan return saham perbankan.

Faktor internal terdiri dari return on asset dan capital adequacy ratio. Return on asset juga merupakan salah satu ratio yang mengukur tingkat profitabilitas suatu perusahaan. Return on asset digunkan untuk mengetahui laba bersih yang dapat diperoleh dari operasional perusahaan dengan menggunakan seluruh kekayaanya. Tinggi rendahnya return on asset tergantung pada pengelolaan asset perusahaan oleh manajemen yang menggambarkan efisiensi dari operasional perusahaan. Semakin tinggi return on asset, semakin efisien operasional perusahaan dan sebaliknya. Rendah nya return on asset dapat disebabkan oleh banyak asset perusahaan yang menganggur investasi dalam persedian yang terlalu banyak, kelebihan uang kertas, aktiva tetap beroperasi dibawah normal lain-lain.

Capital Adequacy ratio (CAR) adalah ratio ratio kecukupan modal yang berfungsi menampung resiko kerugian yang kemungkinan dihadapi oleh bank. Semakin tinggi CAR maka semakin baik kemampuan bank tersebut untuk menanggung resiko dari setiap kredit /aktiva produktif yang beresiko. Jika nilai CAR tinggi maka bank mampu membiayai kegiatan operasional dan memberikan kontribusi yang cukup besar bagi profitabilitas.Faktor eksternal terdiri dari Tingkat Suku Bunga dan Inflasi. Tingkat Suku Bunga, pengertian dari suku bunga adalah harga dari penggunaan uang untuk jangka wktu tertentu atau harga dari penggunaan uang yang dipergunakan pada saat ini dan akan dikembalikan pada saat mendatang dalam mengahadapi kenaikan tingkat suku bunga para pemegang saham akan menahan sahamnya sampai tingkat suku bunga kembali pada tingkat yang di anggap normal. Sebliknya, jika tingkat suku bunga jangka panjang meningkat maka pemegang saham cenderung menjual sahamnya karena harga jualnya tinggi. Pergerakan suku bunga SBI yang fluktuatif dan cenderung meningkat akan mempengaruhi pergerkan sektor riil yang dicerminkan oleh pergerakan return saham. Inflasi merupakan salah satu bentuk penyakit ekonomi yang sering kambuh dan dialami oleh hamper semua Negara. Langkah untuk memerangi inflasi merupakan salah satu fokus dari 
kebijakan ekonomi. Kebijkan yang berkaitang dengan inflasi biasanya dikenal sebagai kebijakan stabilitas harga atau kebijakan untuk mmencapai keseimbangan interen. Definisi sederhana mengenai inflasi menyatakan bahwa inflasi merupakan kecenderungan kenaikan hragharga secara umum dan terus menerus. Dari definisi dapat disimpulkan bahwa kenaikan harga satu atau beberapa barang pada suatu saat tertentu dan hanya sementara belum tentu menimbulkan inflasi.

Menurut Ang (1997) ada dua faktor yang mempengaruhi return suatu investasi yaitu pertama, faktor internal perusahaan seperti kualitas dan reputasi manajemennya, struktur permodalannya, struktur hutang perusahaan, dan sebagainya kedua adalah menyangkut faktor eksternal, misalnya pengaruh kebijakan moneter dan fiskal, perkembangan sektor industrinya, faktor ekonomi misalnya terjadinya inflasi, kenaikan tingkat suku bunga dan sebagainya. Faktorutama yang nampak sangat perpengaruh pada tingkat return saham ialah tingkat inflasi. Tingginya tingkat inflasi menunjukkan bahwa risiko untuk melakukan investasi cukup besar sebab inflasi yang tinggi akan mengurangi tingkat pengembalian (rate of return) dari investor. Peningkatan harga barangbarang dan bahan baku akan membuat biaya produksi menjadi tinggi sehingga akan berpengaruh pada penurunan jumlah permintaan yang berakibat pada penurunan penjualan sehingga akan mengurangi pendapatan perusahaan. Selanjutnya akan berdampak buruk pada kinerja perusahaan yang tercermin pula oleh turunnnya return.

Return menurut Tandelilin (2001), adalah salah satu faktor yang memotivasi investor untuk berinvestasi dan juga merupakan imbalan atas keberanian investor menanggung resiko atas investasi yang dilakukannya. Prihantini (2009). Hal serupa terjadi pada tingkat suku bunga. Perubahan tingkat suku bunga akan mempengaruhi harga saham secara terbalik, ceteris paribus. Hal ini Artinya, jika suku bunga meningkat, maka harga saham akan turun dan sebaliknya. akan berpengaruh pada return saham.

Faktor lain yang mempengaruhi return suatu investasi adalah faktor internal perusahaan. Faktor internal yang digunakan dalam penelitian ini adalah Return On Asset (ROA) dan Capital Adequacy Ratio (CAR). Rasio profitabilitas yang berfungsi dan sering digunakan untuk memprediksi harga saham atau return saham adalah return on asset (ROA) digunakan untuk mengukur efektifitas perusahaan dalam menghasilkan keuntungan dengan memanfaatkan aktiva yang dimilikinya. Jika Return On Asset (ROA) semakin meningkat, maka kinerja perusahaan juga semakin membaik, karena tingkat kembalian semakin meningkat (Hardiningsih et.al., 2002). Prihantini (2009) mengatakan bahwa Return On Asset (ROA) merupakan rasio yang terpenting di antara rasio profitabilitas yang ada untuk memprediksi return saham.

Tujuan dari penelitian untuk mengetahui apakah terdapat pengaruh dari faktor internal (ROA dan CAR) terhadap pengembalian saham perbankan BUMN dan untuk mengetahui apakah terdapat pengaruh dari faktor eksternal (tingkat Suku Bunga dan Tingkat Inflasi terhadap pengembalian saham sektor perbankan BUMN.

\section{REVIEW LITERATUR DAN HIPOTESIS}

\section{Landasan Teori}

1. Return On Asset

Return on asset adalah faktor internal yang digunakan untuk mengukur keefektifan perusahaan dalam menghasilkan keuntungan dengan pemanfaatan aktiva yang dimiliki (Yahya, 2005). Semakin meningkat return on asset berarti 
kinerja perusahaan dalam keadaan bagus, dikarenakan perusahaan dapat memanfaatkan aktiva yang dimiliki dengan optimal, sehingga para investor tertarik untuk berinvestasi pada perusahaan tersebut yang menyebabkan return saham semakin naik (Aryono, 2009).

\section{Capitan Adequancy Ratio (CAR)} Capital adequacy ratio (CAR) adalah ratio-ratio kecukupan modal yang berfungsi menampung resiko kerugian yang kemungkinan dihadapi oleh bank. Semakin tinggi CAR maka semakin baik kemampuan bank tersebut untuk menanggung resiko dari setiap kredit/aktiva produktif yang berisiko. jika nilai CAR tinggi maka bank mampu membiayai kegiatan operasional dan memberikan kontribusi yang cukup besar bagi profitabilitas.

Capital Adequacy Ratio menurut lukman Dendawijaya (2000) adalah raio yang mmeperlihatkan seberapa jauh seluruh aktiva bank yang mengandung resiko (kredit, penyertaan, surat berharga, tagihan pada bank lain) ikut dibiayai modal sendiri bank disamping memperoleh dana dari sumber-sumber di luar bank, seperti dana dari masyarakat, pinjaman dan lain-lain. CAR merupakan indikator terhadap kemampuan bank untuk menutupi penurunan aktivanya sebagai akibat dari kerugian bank untuk menutupi penurunan aktivanya yang berisiko

3. Inflasi

Inflasi merupakan salah satu bentuk penyakit ekonomi yang sering kambuh dan dialami oleh hampir semua Negara. Langkah untuk memerangi inflasi merupakan salah satu fokus dari kebijakan ekonomi. Kebijakan yang berkaitan dengan inflasi biasanya dikenal sebagai kebijakan stabilitas harga atau kebijakan untuk mencapai keseimbangan interen. Defenisi sederhana mengenai inflasi menyatakan bahwa inflasi merupakan kecenderungan kenaikan harga-harga secara umum dan terus menerus. Dari defenisi ini dapat disimpulkan bahwa kenaikan harga satu atau beberapa barang pada suatu saat tertentu dan hanya sementara belum tentu menimbulkan inflasi (Insukindro, 1993).

4. Tingkat Suku Bunga

Pengertian dari suku bunga adalah harga dari penggunaan uang untuk jangka waktu tertentu atau harga dari penggunaan uang yang dipergunakan pada saat ini dan akan dikembalikan pada saat mendatang.

\section{Return Saham}

Return saham adalah tingkat keuntungan yang dinikmati oleh pemodal atas suatu investasi saham yang dilakukannya (Ang, 1997). Secara sederhana investasi dapat diartikan sebagai suatu kegiatan menempatkan dana pada satu atau lebih dari satu aset selama periode tertentu dengan harapan dapat memperoleh penghasilan atau peningkatan nilai investasi.

\section{Penelitian Terdahulu}

Tampubolon (2009) yang melakukan penelitian dengan judul "Pengaruh Kinerja Keuangan terhadap Return Saham Perusahaan Perkebunan yang terdaftar di Bursa Efek Indonesia". Penelitian ini menggunakan rasio keuangan Earning Per Share (EPS), Price Earning Ratio (PER), Debt to Equity Ratio (DER), Return on Investment (ROI), dan Return on Equity (ROE) sebagai variabel independent dan Return saham sebagai variabel dependent. Adapun metode analisis yang digunakan adalah analisis deskriptif dan statistik (pengolahan data SPSS). Hasilnya mengatakan bahwa secara simultan, semua variabel berpengaruh signifikan terhadap return saham dan 
secara parsial EPS,PER, dan ROI memiliki pengaruh yang signifikan sedangkan DER dan ROE memiliki pengaruh positif tapi tidak signifikan.

Ratna Prihantini, (2009) melakukan penelitian dengan judul "Analisis Pengaruh Inflasi, Nilai Tukar, ROA, DER Dan CR Terhadap Return Saham (Studi Kasus Saham Industri Real Estate And Property Yang Terdaftar Di Bursa Efek Indonesia Periode 2003-2006)". Penelitian ini menggunakan nilai tukar, inflasi ROA, DER dan CR sebagai variabel independen (bebas) dan return saham sebagai variabel dependen (variabel terikat) serta menggunakan metode analisis data yakni analisis regresi linier berganda. Adapun hasil dari penelitian ini adalah inflasi, nilai tukar dan DER berpengaruh negatif dan signifikan terhadap return saham, sedangkan ROA dan $\mathrm{CR}$ berpengaruh positif dan signifikan terhadap return saham.

\section{Hipotesis}

H1: Diduga Return on asset (ROA) berpengaruh positif terhadap return saham sektor perbankan di bursa efek indonesia.

H2: Diduga Capital Adequacy Ratio (CAR) berpengaruh positif terhadap return saham sektor perbankan di Bursa Efek Indonesia.

H3: Diduga tingkat inflasi berpengaruh negatif terhadap Return Saham sektor perbankan di Bursa Efek Indonesia.

H4: Diduga tingkat suku bunga berpengaruh negatif terhadap Return saham sektor perbankan di Bursa Efek Indonesia.

\section{METODE PENELITIAN}

\section{Populasi dan Sampel}

Populasi dalam penelitian ini adalah keseluruhan sektor perbankan BUMN yang terdaftar di Bursa Efek Indonesia 2010-2014. Sampel adalah daftar bagian dari jumlah karakteristik yang dimiliki oleh populasi tersebut (Sugiyono, 2008). Pengambilan sampel dilakukan dengan metode purposive sampling, dengan kriteria:

a. Perusahaan perbankan BUMN yang tercatat di Bursa Efek Indonesia selama (tahun 2010-2014).

b. Tersedia data laporan keuangan selama kurun waktu penelitian (tahun 20102014).

c. Data yang di peroleh setiap tahun.

\section{Definisi Operasional}

1. Variabel Independen

a. Return On Asset

Ang (1997) menyatakan menyatakan bahwa ROA diukur dari laba bersih setelah dikurangi pajak (earning after tax) terhadap total asset yang mencerminkan kemampuan perusahaan dalam menghasilkan profitabilitas bagi perusahaan. Secara matematis, ROA dapat dirumuskan sebsi berikut:

$$
R O A=\frac{\text { Laba Sebelum Bunga dan pajak }}{\text { total Ativa }} \times 100 \%
$$

\section{b. Capital Adequacy Ratio}

Capital Adequacy Ratio merupakan rasio permodalan yang menunjukkan kemampuan bank dalam menyediakan dana untuk keperluan pengembangan usaha serta menampung kemungkinan risiko kerugian yang diakibatkan dalam operasional bank. Semakin besar rasio tersebut akan semakin baik posisi modal (Achmad, 2003). Menurut Peraturan Bank Indonesia Nomor 10/15/PBI/2008 pasal 2 ayat 
1 tercantum bank wajib menyediakan modal minimum sebesar $8 \%$ dari aset tertimbang menurut resiko (ATMR), CAR adalah rasio yang memperlihatkan seberapa besar jumlah seluruh aktiva bank yang mengandung resiko (kredit, penyertaan, surat berharga, tagihan pada bank lain) ikut dibiayai dari modal sendiri disamping memperoleh dana-dana dari sumber-sumber diluar bank (PBI, 2008). Rumus CAR sebagai berikut:

$$
C A R=\frac{\text { MODAL SENDIRI }}{A T M R} \times 100 \%
$$

c. Tingkat Inflasi

Inflasi merupakan salah satu bentuk penyakit ekonomi yang sering kambuh dan dialami oleh hampir semua Negara. Langkah untuk memerangi inflasi merupakan salah satu fokus dari kebijakan ekonomi. Kebijakan yang berkaitan dengan inflasi biasanya dikenal sebagai kebijakan stabilitas harga atau kebijakan untuk mencapai keseimbangan interen. Defenisi sederhana mengenai inflasi menyatakan bahwa inflasi merupakan kecenderungan kenaikan harga-harga secara umum dan terus menerus. Dari defenisi ini dapat disimpulkan bahwa kenaikan harga satu atau beberapa barang pada suatu saat tertentu dan hanya sementara belum tentu menimbulkan inflasi (Insukindro, 1993).

\section{d. Tingkat Suku Bunga}

Pengertian dari suku bunga adalah harga dari penggunaan uang untuk jangka waktu tertentu atau harga dari penggunaan uang yang dipergunakan pada saat ini dan akan dikembalikan pada saat mendatang.
2. Variabel Dependen

Return saham juga dapat memberikan gambaran terhadap keuntungan yang dinikmati oleh pemodal atas suatu investasi saham yang dilakukannya. Namun tidak selamanya perusahaan membagikan deviden kas secara periodik kepada pemegang sahamnya, maka return dapat dihitung sebagai berikut (jogiyanto, 1998)

$$
\text { Retrun saham }=\frac{\mathrm{pt}-\mathrm{pt}-1}{p t-1} \times 100 \%
$$

Keterangan :

$\mathrm{Pt}=$ harga saham sekarang

Pt-1 = harga saham sebelumnya

\section{Teknik Analisis Data}

1. Analisis Regresi Data Panel

a. Model Regresi Data Panel

1) Common effect

Estimasi data panel dengan hanya mengkombinasikan data time series dan cross section dengan menggunakan metode OLS. Pendekatan ini tidak memperhatikan dimensi individu atau waktu.

2) Fixed effect

Estimasi data panel dengan mengasumsikan bahwa individu atau perusahaan memiliki intersep yang berbeda, tetapi memiliki slope regresi yang sama. Suatu individu atau perusahaan memiliki intersep yang sama besar untuk setiap perbedaan waktu yang demikian juga dengan koefisien regresinya yang tetap dari waktu ke waktu. Untuk membedkan antar individu yang satu dengan yang lainnya digunakan variabel dummy, sehinnga metode ini sering disebut least square dummy variable (LSDV). 


\section{3) Random Effect}

Estimasi data panel dengan menggunakan residual yang diduga memiliki hubungan antar waktu dan antar individual. Model ini mengasumsikan bahwa setiap variabel mempunyai perbedaan intersep, dan intersep tersebut bersifat random, metode generalized least square (GLS) digunakam untuk mengestimasi model regresi ini.

b. Penentuan Model Regresi Data Panel

1) Regresikan data panel dengan metode common effect.

2) Regresikan data panel dengan metode fixed effect.

3) Makukan pengujian dengan uji chow untuk menentukan apakah metode commom effect atau metode fixed effect yang digunakan.

Prob. Chi square $<0.05$ fixed effect

Prob. Chi square > 0.05 common effect

4) Bila keputusan menerima common effect, maka penentuan model berhenti sampai disini. Berarti model yang tepat adalah common effect (OLS).

5) Bila hasil uji chow memberikan keputusan menerima fixed effect, lanjutkan meregresikan data panel dengan rondom effect.

6) Lakukan pengujian dengan uji hausman apakah metode fixed effect atau random effect yang akan digunakan. Jika Prob. Cross section random < 0.05 fixed effect, dan jika Prob. Cross section random $>0.05$ random effect.

c. Model Regresi Data Panel

Teknik analisis yang digunakan adalah model regresi data panel yang persamaannya dapat dituliskan sebagai berikut:

$\mathrm{Y}=\mathrm{a}+\mathrm{b} 1 \mathrm{X} 1+\mathrm{b} 2 \mathrm{X} 2+\mathrm{b} 3 \mathrm{X} 3+\mathrm{b} 4 \mathrm{X} 4$ keterangan:

$\mathrm{Y}=$ Return Saham

$\mathrm{X} 1=$ Return On Asset

$\mathrm{X} 2=$ Capital Adequacy Ratio

X3= Tingkat Inflasi (IHK)

X4= Tingkat Suku Bunga (SBI)

b $1 \ldots . . . b 4=$ Koefisien regresi

$\alpha=$ konstanta

\section{Uji Hipotesis}

1. Uji Parsial (Uji T)

Uji-t dilakukan untuk mengetahui pengaruh masing-masing rasio keuangan secara individu terhadap minimalisasi resiko. Pengujian ini dimaksudkan untuk melihat apakah secara individu variabel independen mempunyai pengaruh terhadap variabel dependen, dengan asumsi variabel independen lainnya konstan. Pengujian ini dilakukan sebagai berikut:

a. Jika t-hitung < t-tabel maka $\mathrm{Ha}$ ditolak, berarti variabel independen secara parsial tidak mempengaruhi variabel dependen.

b. Jika t-hitung > t-tabel maka Ha diterima, berarti variabel independen secara parsial mempengaruhi variabel dependen.

\section{Uji Koefisien Determinasi}

Digunakan untuk mengetahui keeratan hubungan antara variabel bebas dengan variabel terikat. Nilai R2 terletak antara 0 sampai dengan $1(0 \leq$ $\mathrm{R} 2 \leq 1)$. Tujuan menghitung koefisien determinasi adalah untuk mengetahui pengaruh variabel bebas terhadap variabel terikat. 


\section{HASIL PENELITIAN DAN PEMBAHASAN}

\section{Hasil Analisis Deskriptif}

\begin{tabular}{|l|l|l|l|l|l|}
\hline Variabel & N & Minimum & Maximum & Mean & Std.dev \\
\hline Return saham $(\mathrm{Y})$ & 4 & -40 & 104,91 & 24,06 & 36,49 \\
\hline ROA $\left(\mathrm{X}_{1}\right)$ & 4 & 0,77 & 3,69 & 2,36 & 0,815 \\
\hline CAR $\left(\mathrm{X}_{2}\right)$ & 4 & 13 & 18 & 15,6 & 1,39 \\
\hline INFLASI $\left(\mathrm{X}_{3}\right)$ & 4 & 3,79 & 8,38 & 6,35 & 2,01 \\
\hline $\begin{array}{l}\text { SUKU } \\
\text { BUNGA }\left(\mathrm{X}_{4}\right)\end{array}$ & 4 & 5,75 & 7,75 & 6,7 & 0,81 \\
\hline
\end{tabular}

a. Return saham adalah tingkat keuntungan yang dinikmati oleh pemodal atas suatu investasi saham yang dilakukannya (Ang, 1997). Secara sederhana investasi dapat diartikan sebagai suatu kegiatan menempatkan dana pada satu atau lebih dari satu asset selama periode tertentu dengan harapan dapat memperoleh penghasilan atau peningkatan nilai investasi. Konsep risiko tidak terlepas dari kaitanya dengan return karena investor selalu mengharapkan return yang sesuai atas setiap risiko investasi yang dihadapinya. Hasil pengolahan data dapat dilihat dari tabel menyatakan bahwa Return saham memiliki minimum -40 dan nilai maximum 104,91 return saham selama periode penelitian memiliki rata-rata sebesar 24,06 dengan standar devisiasi 36,49 hal ini menunjukan bahwa Return saham memiliki nilai kecil karena standar devisiasi lebih kecil dari pada nilai rata-rata.berdasarkan hasil perhitungan diatas tampak bahwa selama periode penelitian tahun 20102014 besarnya return saham pada perusahaan Bank BUMN tidak memenuhi standar devisiasi dengan nilai maximum mencapai 104,91 pada tahun 2010.

b. Return On Asset sering disebut rentabilitas ekonomi, merupakan ukuran kemampuan perusahaan dalam menghasilakn laba semua aktiva yang dimiliki perusahaan termasuk dalam hal ini laba yang dihasilkan adalah laba sebelum pajak. ROA pada tahun 2010 hingga 2014 memiliki ratarata sebesar 2,36 dengan standar devisiasi 0,815 nilai minimum untuk variabel ROA sebesar 0,77 dan nilai maximum sebesar 3,69. hal ini menunjukan bahwa ROA memiliki niliai tinggi karena standar devisiasi lebih kecil dari pada nilai ratarata.Berdsarkan hasil perhitungan diatas tampak bahwa selama periode penelitian tahun 2010 hingga 2014 besaranya return on asset pada perusahaan Bank Bumn memenuhi standar dengan nilai maximum mencapai 3,69 pada tahun 2010 sedangkan nilai minimummencapai 0,77 pada tahun 2014 .

c. Capital Adequacy Ratio (CAR), ratio kecukupan modal yang berfungsi menampung risiko kerugian yang kemungkinan dihadapi dihadapi oleh bank. Semakin tinggi CAR maka semakin baik pula kemampuan bank tersebut untuk menanggung risiko dari setiap kredit/atktiva produktif yang bersiko. Jika nilai CAR tinggi maka bank mampu membiayai kegiatan operasional dan memberikan kontribusi yang cukup besar bagi profitabilitas. Berdasrakan hasil pengolahan data menyatakan bahwa CAR yang diteliti memiliki rata-rata $15,6 \%$ dan standar devisiasi $1,39 \%$ dengan nilai minimum sebesar $13 \%$ dannilai maximum sebesar $18 \%$ hal ini menunjukan bahwa CAR yang diteliti memiliki nilai kecil karena nilai standar devisiasi lebih kecil dari pada nilai rata-rata. Berdasarkan perhitungan diatas tampak bahwa selama periode 2010 hingga 2014 besarnya CAR pada perusahaan Bank Bumn memenuhi standar dengan nilai maksimum mencapai 23 pada tahun 2010 sedangkan nilai minimum mencapai 13 pada tahun 2014.

d. Tingkat Inflasi daapat dijelaskan sebagai bentuk penyakit ekonomi yang sering kambuh dan dialami oleh hampir semua negara. langkah untuk 
memerangi inflasi merupakan salah satu fokus dari kebijakan ekonomi kebijakan yang berkaitan dengan inflasi biasanya dikenal sebagai kebijakan stabilitas harga atau kebijakan untuk mencapai keseimbangan inrteren, definisi sederhana mengenai inflasi menyatakan bahwa inflasi merupakan kecenderungan kenaiakan harga secara umum dan terus menerus. Berdasrakan hasil pengolahan data menyatakan bahwa inflasi yang diteliti besarnya inflasi pada perusahaan bank bumn tidak memenuhi standar dengan nilai masksimum sebesar $8,38 \%$ dan nilai minimum sebesar $3,79 \%$ sedangkan nilai rata-rata sebesar $6,35 \%$ dan nilai standar 2,01\% pada tahun 2010-2014.

e. Suku Bunga dapat diartikan sebagai dari penggunaan uang untuk jangka waktu tertentu atau harga dari penggunaan uang yang dipergunakan pada saat ini dan akan dikembalikan pada saat mendatang. Berdasarkan perhitungan data yang diolah menunjukan bahwa suku bunga mempunyai nilai maksimum sebesar $7,75 \%$ dan nilai minimum sebesar $5,75 \%$ sedangkan nilai rata-rata suku bunga sebesar $6,7 \%$ dan nilai standar sebsar $0,81 \%$. dengan demikian perhitungan menunjukan bahwa nilai suku bunga tinggi, karena nilai standar devisiasi suku bunga sebesar $0,81 \%$ lebih kecil dari pada nilai rata-rata.

\section{Hasil Penelitian}

1. Hasil Uji Regresi Data Panel

\begin{tabular}{l|l|l|l|}
\hline Variabel & Koefisient & Std.erorr & t.statistik \\
\hline C & 57.20121 & 149.4744 & 0.382682 \\
\hline ROA & 5.742461 & 9.756569 & 0.588574 \\
\hline CAR & 9.040008 & 5.668604 & 1.594750 \\
\hline INFLASI & 24.14000 & 11.42023 & 2.113793 \\
\hline SUKU BUNGA & -50.93212 & 28.22223 & -1.804681 \\
\hline \multicolumn{3}{|c|}{ Return saham $=57,20121+$} \\
5,742461ROA + 9.040008CAR + \\
24,14000Inflasi + -50,93212Suku \\
Bunga
\end{tabular}

Persamaan di atas dapat menunjukan nilai intercept (c) sebesar 57,20121, Artinya tanpa Roa, Car, inflasi, dan suku bunga besarnya variabel return saham sebesar 57,20121

Koefisien regresi variabel ROA sebesar $5.742461 \%$ dapat diartikan bahwa setiap kenaikan ROA 1 satuan maka Return saham maka naik $5.742461 \%$ sebaliknya jika variabel Return saham turun 1 satuan maka Return saham turun sebesar 5.742461

Koefisien regresi variabel CAR sebesar 9.040008 dapat diartikan bahwa setiap kenaikan CAR 1 satuan maka return saham akan naik sebesar 9.040008 sebaliknya jika CAR turun 1 satuan maka Return saham naik sebesar 9.040008.

Koefisien regresi variabel inflasi sebesar 24,14000 dapat diartikan bahwa setiap kenaikan inflasi 1 satuan maka akan menaikkan Return saham sebsar 24,14000 sebaliknya setiap inflasi turun 1 satuan maka return saham akan turun sebesar 24,14000.

Koefisien regresi variabel suku bunga sebesar -50,93212 dapat diartikan bahwa setiap kenaikan suku bunga 1 satuan maka menurunkan return saham sebesar $-50,93212$. sebaliknya setiap suku bungan turun 1 satuan maka return saham akan naik sebesar $-50,93212$.

2. Hasil Uji Parsial (Uji T)

\begin{tabular}{|l|c|c|l|}
\hline \multicolumn{1}{|c|}{ Variabel } & t-statistik & t-tabel & \multicolumn{1}{c|}{ Ket } \\
\hline ROA & 0.588574 & 1.746 & Ha ditolak \\
\hline CAR & 1.594750 & 1.746 & Ha ditolak \\
\hline INFLASI & 2.113793 & 1.746 & Ha ditolak \\
\hline $\begin{array}{l}\text { SUKU } \\
\text { BUNGA }\end{array}$ & -1.804681 & 1.746 & Ha diterima \\
\hline
\end{tabular}

a. Hasil uji-t nilai (ROA) sebesar:0.588574 lebih kecil dari t-tabel $1.746(0.588574<1.746)$ ini menunjukan menolak Ha yaitu ROA tidak berpengaruh positif signifikan terhadap kebijakan return saham perusahaan perbankan yang terdaftar di bursa efek indonesia tahun 20102014. 
b. Hasil uji-t nilai kebijakan CAR sebesar: 1.594750 lebih kecil dari ttabel $1.746(1.594750<1.746)$. ini menunjukan menolak HA yaitu CAR tidak berpengaruh positif signifikan terhadap return saham perbankan yang terdaftar di Bursa Efek Indonesia pada tahun 20102014.

c. Hasil uji-t nilai inflasi sebsar 2.113793 lebih besar dari t-tabel $(2.113793>1.746)$ hal ini menunjukan menolak Ha yaitu inflasi berpengaruh positif terhadap retun saham perbankan yang terdaftar di Bursa Efek Indonesia pada tahun 2010-2014.

d. Hasil uji-t nilai suku bunga sebsar -1.804681 lebih besar dari ttabel sebesar $1.746(-(1.804681)>1.746)$. hal ini menunjukan menerima $\mathrm{Ha}$ nilai suku bunga berpengaruh negatif terhadap return saham perbankan yang terdaftar di Bursa Efek Indonesia pada tahaun 20102014.

3. Hasil Uji Koefisien Determinasi

\begin{tabular}{|c|l|}
\hline R-squared & 0.334216 \\
\hline Koefisien determinasi (R2)
\end{tabular}

menunjukan berapa besar variabel independen mampu menjelaskan variabel dependen koefisien determinasi R2 dalam penelitian ini sebesar 0,334216 atau 33,42\%. Hal tersebut menunjukkan bahwa variabel ROA, CAR, Inflasi dan Suku bunga mampu menjelaskan return saham sebesar 33,42\%, dan sisanya sebesar $66,58 \%$ dijelaskan oleh variabel lain diluar dari variabel yang diteliti.

\section{Pembahasan}

1. Pengaruh ROA terhadap return saham perbankan (H1)

Dari hasil pengujian yang dilakukan antara kebijakan yang diproksikan dengan ROA terhadap return saham perbankan, variabel ROA tidak berpengaruh terhadap return saham perbankan. Hal ini terjadi dikarenakan beberapa faktor diantaranya adalah perusahaan dalam subsektor perdagangan ini memiliki data komponen ROA yaitu laba setelah pajak dan total aset yang tidak stabil pada setiap tahun selama periode penelitian Alasan lain adalah adanya perbedaan jenis sektor perusahaan yang diteliti saat ini dengan penelitian terdahulu. Sebab, setiap jenis sektor atau subsektor perusahaan di BEI memiliki komposisi yang berbeda, baik ukuran perusahaan ataupun jenis perusahaannya.

2. Analisis Pengaruh CAR terhadap return saham perbankan $(\mathrm{H} 2)$.

Dari hasil pengujian diatas CAR terhadap return saham perbankan menunjukan bahwa tidak berpengaruh signifikan terhadap return saham perbankan. Tidak berpengaruhnya CAR bank-bank yang beroperasi pada tahun tersebut tidak mengoptimalkan modal yang ada. CAR tidak berpengaruh terhadap return saham yang merupakan proksi dari kinerja bank umum. Hal ini terjadi karena peraturan Bank Indonesia yang mensyaratkan CAR minimal $8 \%$ mengakibatkan bank-bank selalu berusaha menjaga agar CAR yang dimiliki sesuai dengan ketentuan. Namun bank cenderung menjaga CARnya tidak lebih dari 8 persen karena ini berarti pemborosan. Hal tersebut juga dapat terjadi karena bank belum dapat melempar kredit sesuai dengan yang diharapkan atau belum optimal (Mawardi, 2005).

3. Pengaruh inflasi terhadap return saham (H3).

Dari hasil uji-t diperoleh bahwa inflasi berpengaruh positif terhadap pengembalian saham. Jika nilai inflasi naik 1 satuan maka nilai return saham akan naik sebesar 24.1400 dan 
sebaliknya jika nilai inflasi turun 1 satuan maka nilai return saham akan turun sebesar 24.14000. Fischer mengatakan dirinya tidak setuju dengan argumen bahwa target inflasi bank sentral diharuskan didorong untuk 4 $\%$ dia merasa keuntungan dalam inflasi fed $2 \%$ memberikan ruang untuk manuver jika perlu untuk merangsang ekonomi, sementara juga mendorong perusahaan untuk meningkatkan upah dengan harapan harga dapat lebih tinggi dan pendapatan yang lebih kuat. Fed harus menjaga inflasi secara signifikan dibawah $4 \%$ lebih mudah bagi perusahaan untuk menanggapi harga stagnam atau menurun dengan pemotongan upah dan mendukung penelitian yang dilakukan oleh Prihantini, (2009) melakukan penelitian dengan judul "Analisis Pengaruh Inflasi, Nilai Tukar, ROA, DER Dan CR Terhadap Return Saham (Studi Kasus Saham Industri Real Estate And Property Yang Terdaftar Di Bursa Efek Indonesia Periode 2003-2006)". Penelitian ini menggunakan nilai tukar, inflasi ROA, DER dan CR sebagai variabel independen (bebas) dan return saham sebagai variabel dependen (variabel terikat) serta menggunakan metode analisis data yakni analisis regresi linier berganda. Adapun hasil dari penelitian ini adalah inflasi, nilai tukar dan DER berpengaruh negatif dan signifikan terhadap return saham.

4. Pengaruh suku bunga terhadap return saham (H4)

Dari hasil uji-t menunjukan Pengaruh Nilai Suku Bunga terhadap return saham perbankan menunjukan bahwa berpengaruh negatif terhadap return saham perbankan. Dalam menghadapi kenaikan suku bunga, para pemegang saham akan menahan sahamnya sampai tingkat suku bunga kembali pada tingkat yang dianggap normal. Sebaliknya, jika tingkat suku bunga jangka panjang meningkat maka pemegang saham cenderung menjual sahamnya karena harga jualnya tinggi. Kenaikan suku bunga akan sangat berpengaruh bagi pelaku pasar modal. Pergerakan suku bunga SBI yang fluktuatif dan cenderung meningkan akan mempengaruhi pergerakan sektor riil yang dicerminkan oleh pergerakan return saham. Jika nilai nilai suku bunga naik 1 satuan maka nilai return saham turun sebesar 50,9321 dan sebaliknya jika nilai suku bunga turun 1 satuan maka nilai return saham akan naik sebesar 50,9321 .

\section{KESIMPULAN DAN SARAN}

\section{Kesimpulan}

1. Dari hasil ujit-t menunjukan bahwa ROA (Return On Asset) tidak berpengaruh positif terhadap pengembalian saham pada perusahaan Bank BUMN di BEI.

2. Dari hasil uji-t menunjukan bahwa CAR (Capital Adequacy Ratio) tidak berpengaruh positif terhadap pengembalian saham pada perusahaan Bank BUMN di BEI.

3. Dari hasil uji-t menujukan bahwa Tingkat Inflasi berpengaruh positif terhadap pengembalian saham pada perusahaan di perusahaan Bank BUMN BEI.

4. Dari hasil uji-t menunjukan bahwa Tingkat suku bunga berpengaruh negatif terhadap pengembalian saham pada perusahaan perusahaan Bank BUMN di BEI.

5. Koefisien Determinasi R2 sebesar 0.334216 atau $33,42 \%$ menunjukan bahwa variabel ROA, CAR, Inflasi, suku bunga mampu menjelaskan return 
saham sebesar $33,42 \%$ dan sisanya sebesar $66,58 \%$ dijelaskan oleh variabel lain diluar dari variabel yang diteliti.

\section{Saran}

1. Penelitian mengenai return saham ini hanya terbatas pada informasiinformasi internal masing-masing sektor perbankan. Oleh karena itu, disarankan agar penelitian selanjutnya juga menggunakan sampel dengan karakteristik yang beragam dan jumlah sampel yang lebih banyak, periode pengamatan yang lebih lama serta mempertimbangkan variabel internal lainnya dan faktor eksternal lainnya pula.

2. Bagi investor disarankan mempertimbangkan faktor eksternal perusahaan disamping faktor fundamental seperti kondisi ekonomi baik secara nasional maupun global, kondisi politik dan hukum agar keputusan investasi pada suatu perusahaan lebih tepat.

3. Bagi penelitian hal ini diharapkan dapat memberikan tambahan wacana penelitian yang berkaitan dengan factor-faktor yang mempunyai pengaruh terhadap pengembalian saham, perbandingan dengan penelitian yang dilakukan apabila searah dengan penelitian ini.

\section{DAFTAR PUSTAKA}

Ang, Robert. (1997) Buku Pasar Modal Indonesia. Jakarta: Media Soft Indonesia.

Aryono, Sri Isworo. (2009). Pengaruh Right Issue Terhadap Kinerja Keuangan Pada Perusahaan Yang Terdaftar Di Bursa Efek Indonesia. Hasil Penelitian Dosen
Dan Seminar Nasional, Surabaya 30 April 2009.

Dendawijaya L. (2005). Manajemen Perbankan. Bogor: Ghalia Indonesia.

Prihantini, Ratna. (2009). Analisis Pengaruh Inflasi, Nilai Tukar, ROA, DER Dan CR Terhadap Return Saham (Studi Kasus Saham Industri Real Estate And Property Yang Terdaftar Di Bursa Efek Indonesia Periode 2008 2012). Tesis Magister Manajemen. Universitas Diponegoro Semarang. Sugiyono. (2008). Metode Penelitian Administrasi dilengkapi dengan Metode $R \& D$. Edisi Revisi Cetakan ke-16. Bandung: Alfabeta.

Tandelilin. Eduardus. (2001). Analisis Investasi Dan Manajemen Portofolio. Yogyakarta: BPFE.

Yahya, Riyani Irma. (2005). Analisis Price Earning Ratio, Price To Book Value, Debt To Equity Ratio, Return On Asset, Dan Net Profit Margin Terhadap Return saham. 